\title{
Alkaline intrusion in a granulite ensemble in the Eastern Ghats belt, India: Shear zone pathway and a pull-apart structure
}

\author{
S BhattacharyA ${ }^{1 *}$ and RAjib $\mathrm{KAR}^{2}$ \\ ${ }^{1}$ Geological Studies Unit, Indian Statistical Institute, 203 B. T. Road, Kolkata 700 108, India. \\ *e-mail: samar@isical.ac.in \\ ${ }^{2}$ Department of Geology, J.K. College, Purulia 723 101, India.
}

The alkaline complex of Koraput, Orissa, India, is one of several bodies in the high-grade Eastern Ghats belt, but this one is an integral part of the high-grade belt and remote from the western boundary against the Bastar craton. The Koraput complex forms a lozenge-shaped intrusion into the metapelitic granulites and is bounded by shear zones. The combined effect of movement along these shear zones, is a northeasterly elongated sygmoidal cavity with maximum width along the northwesterly trending Reidel shear. Thus the Koraput alkaline complex can be considered to have been emplaced in a pull-apart structure, developed in the granulitic country rocks. Moreover, in view of the fact that the western margin of the high-grade Eastern Ghats belt bears clear evidence of collisional features, rather than that of rifting or break-up, the rift-valley model for the alkaline magmatism in this high-grade belt appears untenable.

\section{Introduction}

Apart from Benioff zone-related magmatism and continental flood basalts, igneous activity on continents is restricted to rift valleys and local hotspots (Bailey 1974). While continental flood basalts are more common along successful branches of rift systems, alkaline magmatism predominates along failed arms normally preserved within continents (Philpotts 1990). However, except for the modern rift systems such as that of east Africa, the relation between tectonism and magmatism have not been precisely determined. On the other hand, some continental alkaline rocks, such as those of White Mountains in New Hampshire, Canada, do not appear to be associated with rift valleys, but instead form elongate belts that may trace the paths of continents over mantle plumes.

Several exposures of alkaline complex have been reported from the high-grade Eastern Ghats belt, India, but no in-depth study of the structural setting has yet been undertaken (Leelanandam 1998 and references therein). Such a study is expected to discriminate between the two alternative models: rift-valley magmatism or plume tectonics. In this paper, we describe the preliminary structural setting of the Koraput alkaline complex in terms of the structural framework of the high-grade Eastern Ghats belt and thereby reveal the relation between tectonism and alkaline magmatism.

\section{Geological setting}

The lithological make-up of the Eastern Ghats belt, along the east coast of India and bounded by Singhbhum and Bastar cratons to the north and west respectively, could be described in terms of three broad groups, namely, metapelitic granulites; charnockite-enderbite gneisses and associated granulites; and migmatitic gneisses (figure 1). Additionally, a transition zone occurs along a significant length of the western margin. Anorthosites and alkaline complexes are other important rock

Keywords. Alkaline magmatism; Eastern Ghats belt; pull-apart structure; plume tectonics. 


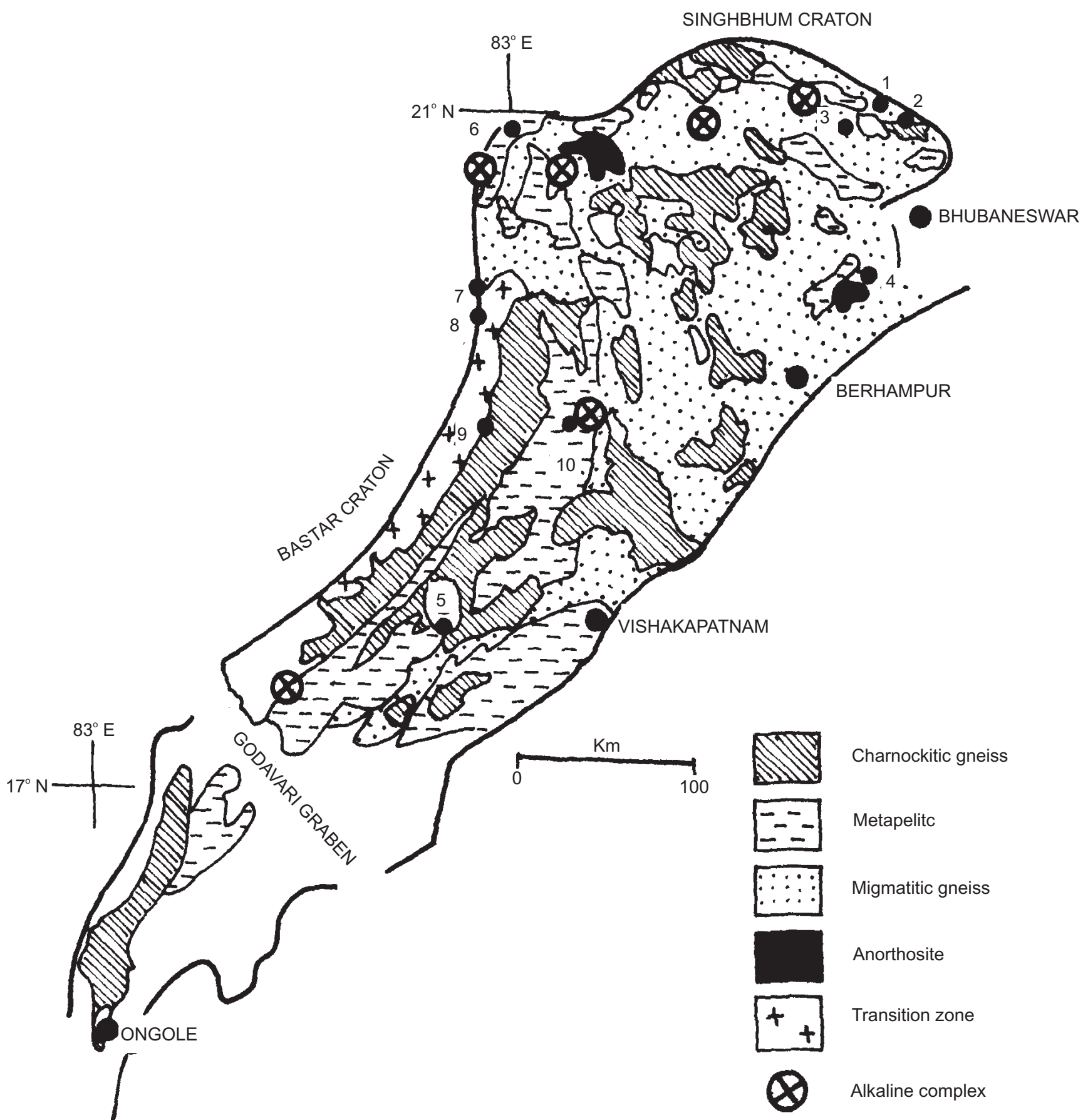

Figure 1. Generalized geological map of the Eastern Ghats belt, modified after Ramakrishnan et al 1998. Important locations: 1. Bhuban, 2. Jenapore, 3. Angul, 4. Chilka, 5. Paderu, 6. Paikmal, 7. Deobhog, 8. Lakhna, 9. Jaypur, 10. Koraput.

types in this high-grade belt. This belt has the imprints of three major episodes of folding and associated metamorphic fabrics, developed on various scales (Sarkar et al 1981; Halden et al 1982; Bhattacharya et al 1994; Bhattacharya 1997). Complex, multi-stage granulite facies metamorphism is also evident in a few localities (Sen et al 1995; Bhattacharya et al 2003). On the evidence of NE-SW regional tectonic trend, represented by $S_{1}$ gneissosity, a steep axial planar foliation; and common structural repetitions, the Eastern Ghats belt could be described as a convergent orogen that evolved under a regional NW-SE directed compression and attendant homogeneous shortening (Bhattacharya et al 2001).

\section{Lithology and field relations}

Four main lithological varieties of alkaline rocks could be identified in the field, namely: 


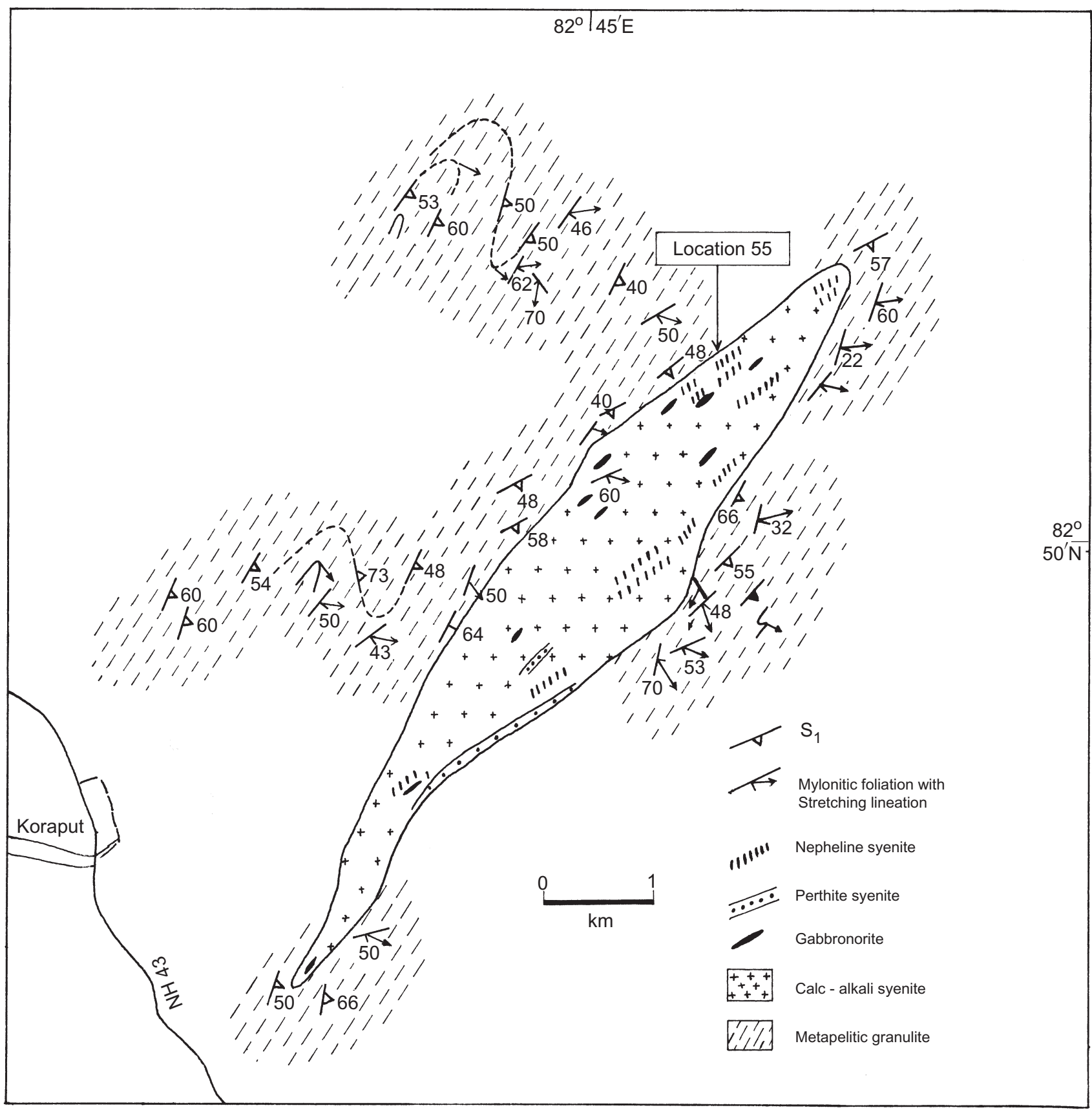

Figure 2. Geological map of the area around the alkaline complex of Koraput.

(i) mesocratic and coarse, equigranular, syenite (with neither quartz nor nepheline);

(ii) melanocratic, fine grained syenite;

(iii) commonly foliated nepheline syenite and

(iv) coarse grained leucocratic syenite.

The central part of the body is mostly occupied by the mesocratic syenite, while melanocratic syenite occurs as small bands, commonly enclosed by the mesocratic syenite. Nepheline syenite mostly occurs along the border. Leucocratic syenite occurs partially along the southeast border (figure 2). Intrusive contacts, particularly of melanocratic syenite against pelitic granulites with a pervasive gneissic foliation, is common (figure 3a). Leucocratic syenite also occurs as cross-cutting veins in melanocratic syenite (figure 3b). Foliation, particularly, in the mesocratic syenite, is defined by parallel alignment of mafic minerals, mostly amphibole, could be a magmatic foliation (figure $3 \mathrm{c}$ ). Some cross-cutting veins in the mesocratic syenite are fine-grained variety of the host syenite, and hence could be shear veins (figure 3c). On the basis of modal compositions (table 1), the four lithological types could be described as calc-alkali syenite; gabbro-norite; nepheline syenite and perthite syenite respectively (Streckeisen 1976). 


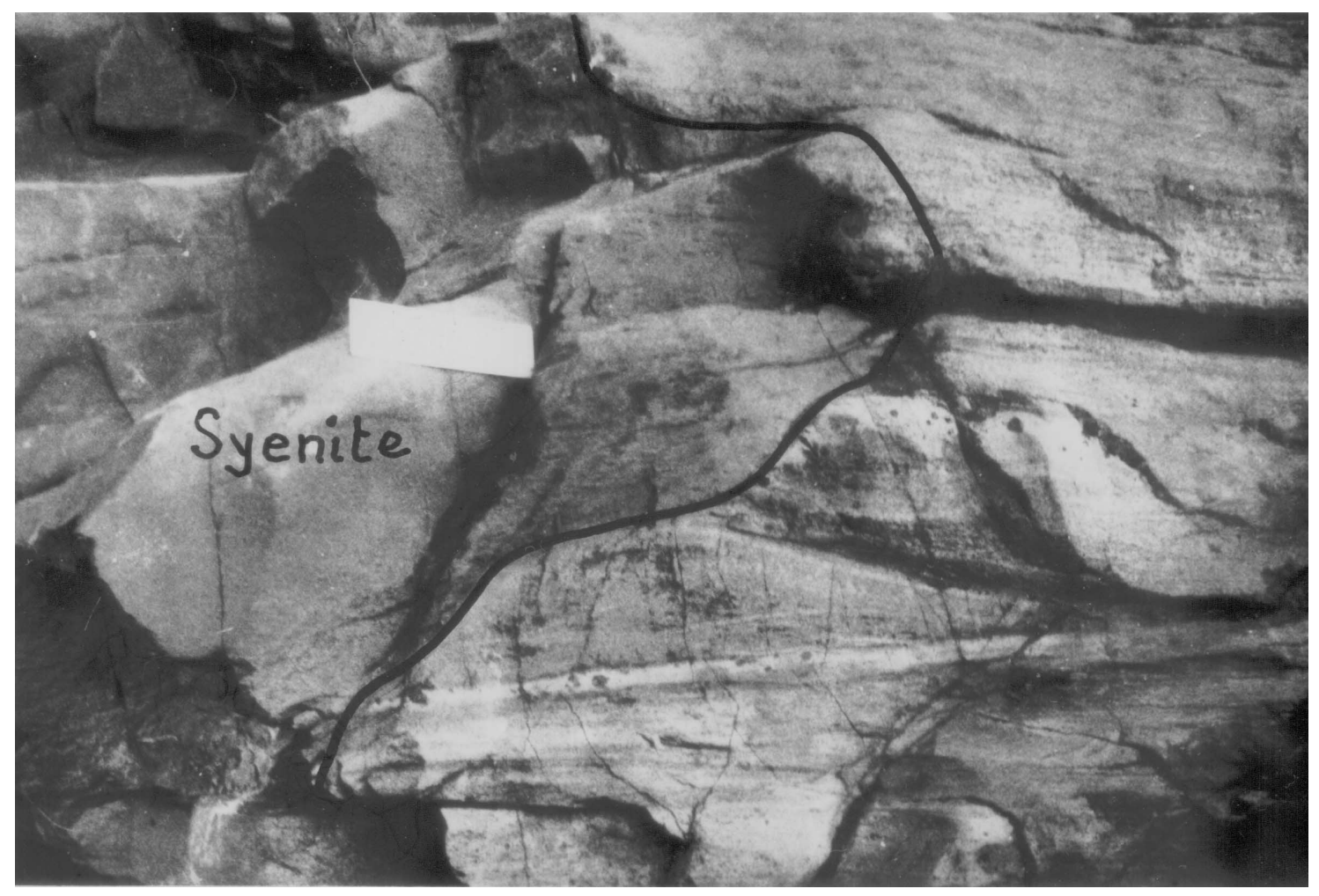

Figure 3(a). Intrusive contact of melanocratic syenite with metapelitic granulites; pervasive gneissic foliation in the pelitic granulites abuts against the syenite boundary.

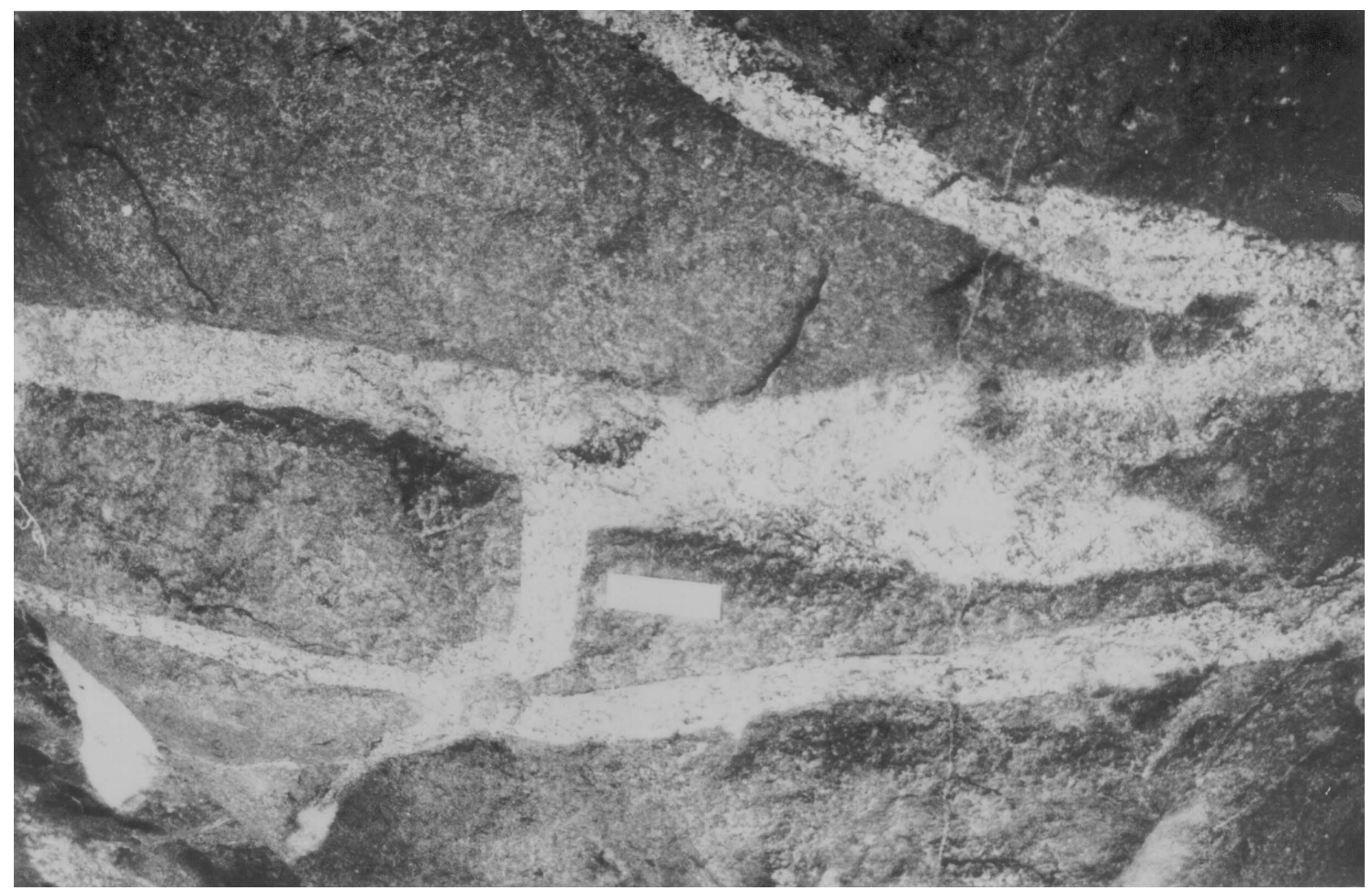

Figure 3(b). Branching veins of leucocratic syenite within melanocratic syenite. 


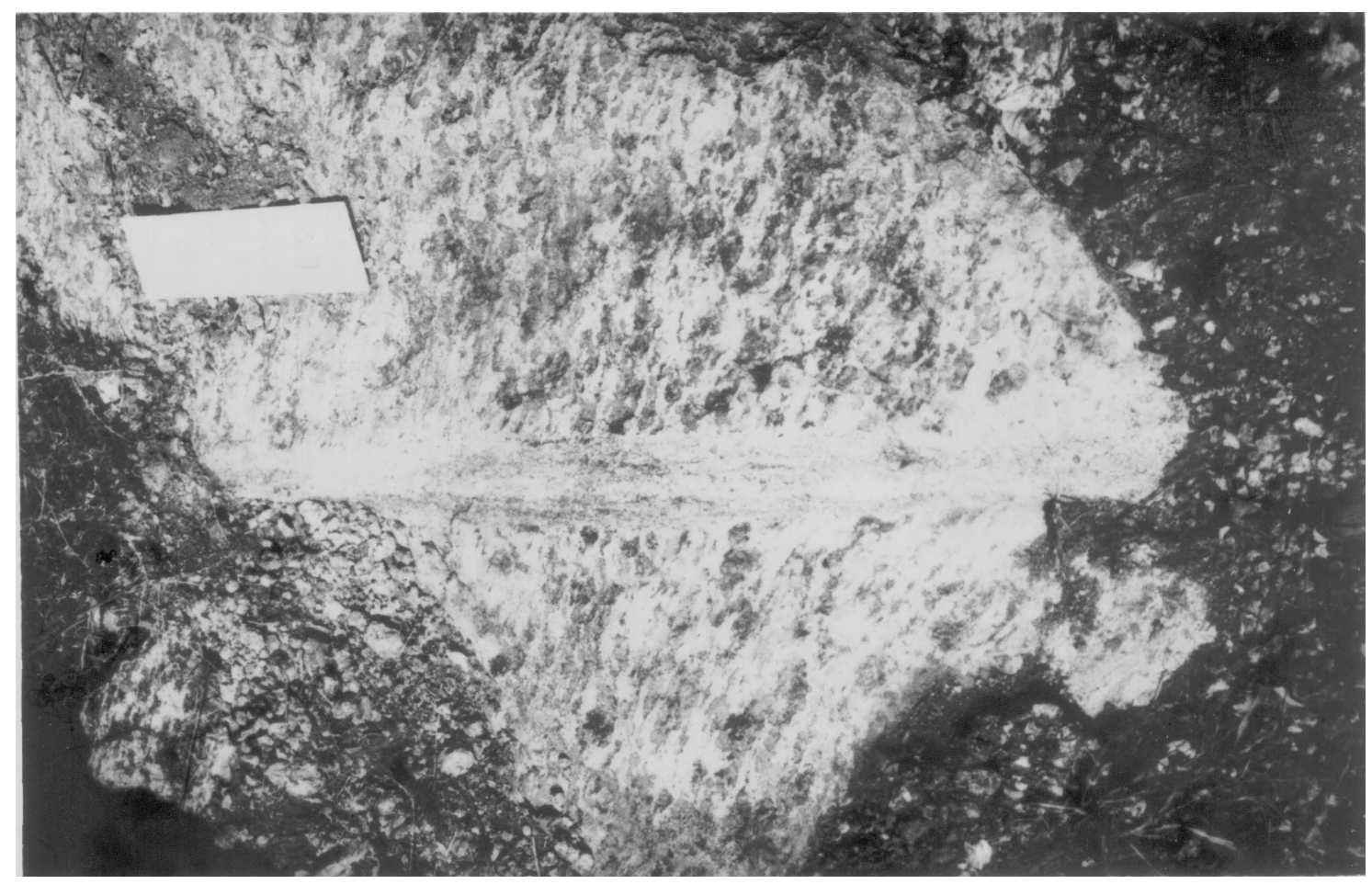

Figure 3(c). Foliation in mesocratic syenite defined by parallel arrangement of mafic minerals; also a fine-grained vein across the foliation is compositionally not different from the host syenite, and could be a shear vein.

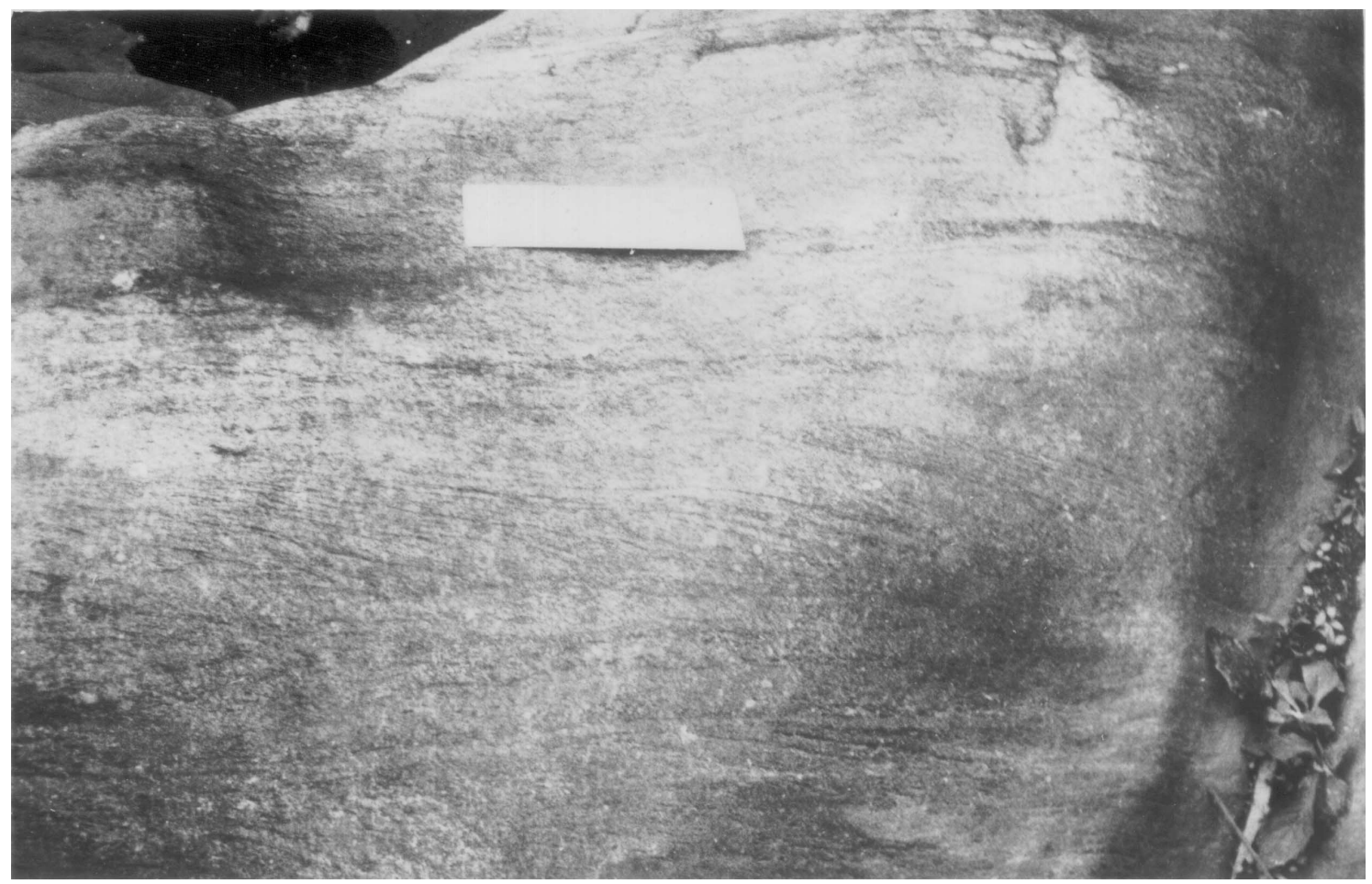

Figure 3(d). A small-scale shear zone in metapelitic granulite, close to the alkaline body, depicts S-C mylonitic fabrics: continuous (east-west) one is the cleavage $\mathrm{C}$ and discontinuous oblique one is the mylonitic banding $\mathrm{S}$. 


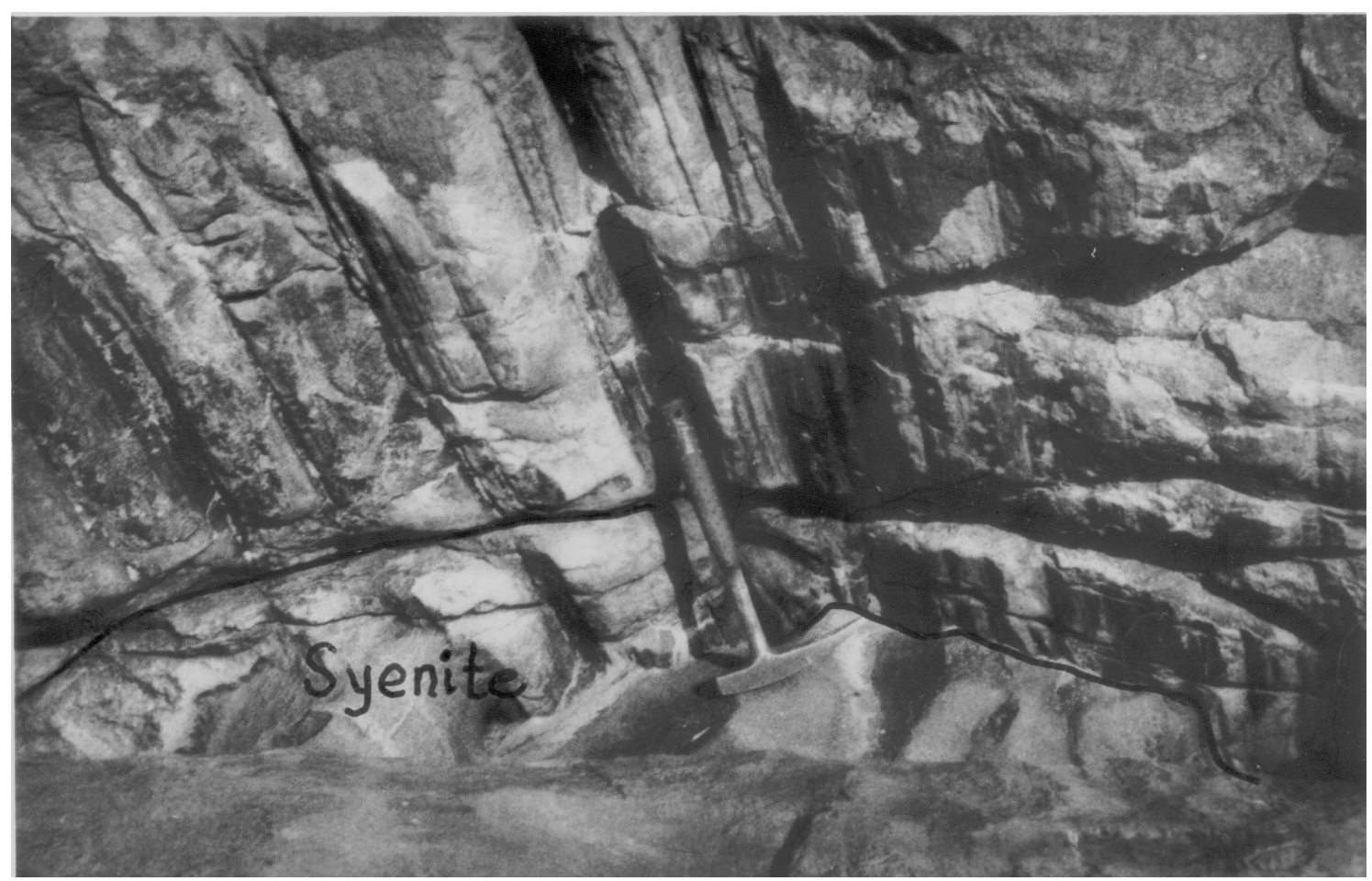

Figure 3(e). Striping lineation on mylonitic foliation, in metapelitic granulite, abuts against the boundary of an elliptical body of alkaline rock.

\section{Structural setting}

The NNE-SSW oriented, lozenge-shaped body of the alkaline complex with long dimension of $4 \mathrm{~km}$ and maximum width of $0.75 \mathrm{~km}$ is intrusive into metapelitic granulites. The gneissic foliation, $S_{1}$ in metapelitic granulites is axial planar to the rootless folds defined by the quartzite bands. This gneissic foliation displays some mesoscopic folds, particularly on the western side of the alkaline body and these folds are commonly overturned to isoclinal with steep easterly plunges (figure 2). On the other hand, shear zones traverse the host metapelites near the alkaline complex boundary and commonly transpose the typical gneissic foliation (figure 3d). Sometimes, the stretching lineation on the mylonitic foliation abuts against intrusive melanocratic syenite body in the contact region (figure 3e). Two sets of mylonitic foliation are observed. The dominant shear planes are northeasterly trending with moderate southeasterly dip (figures 2 and $4 \mathrm{a}$ ). The stretching lineation on them is oblique towards north, indicating a significant (sinistral) strike slip component (figure 2). The microstructures observed in the $\mathrm{X}-\mathrm{Z}$ section (parallel to stretching lineation and normal to shear plane) indicate a normal-fault sense of shear (figures 5a and 5b). A set of subsidiary shear planes developed with northwesterly trend and steep southerly dip, with mostly down-dip stretching lineation (figure 4a). Microstructures indicate a reverse-fault sense of movement; possibly representing a Reidel shear. Also, mesoscopic field survey on a shear lens bounded by two nearly parallel (dominant northeasterly trending) shear zones is consistent with sinistral-top towards northwest normal fault sense of movement (figure 6). Mesoscopic field survey in the contact region (location 55, marked in figure 2), also reveals unusual fold geometry in metapelitic country rock. Unlike the reclined $F_{2}$ folds away from the alkaline body, here the gneissic foliation describes upright folding on mesoscopic scale (figure 4b). This is presumably the result of some sub-horizontal compression related to the emplacement of the alkaline magma.

Also, the magmatic foliation within alkaline rocks: parallel alignment of mafic minerals in nepheline syenite, compositional banding and parallel alignment of feldspars in perthite syenite, is consistently northeasterly trending and steep southeasterly dipping (figure 4c), indicating the passage of magma along dominant shear planes.

All these observations and structural and kinematic evidence indicate that the present alkaline complex is bounded by shear zones. The combined effect of movement on these shear planes is a sygmoidal gap with maximum width along the strike of the subsidiary, northwesterly trending shear plane. The shape and orientation of the alkaline body perfectly matches with this sygmoidal gap and hence can be considered to have been emplaced in a pull-apart structure (figure 7). 
Shear zone pathway

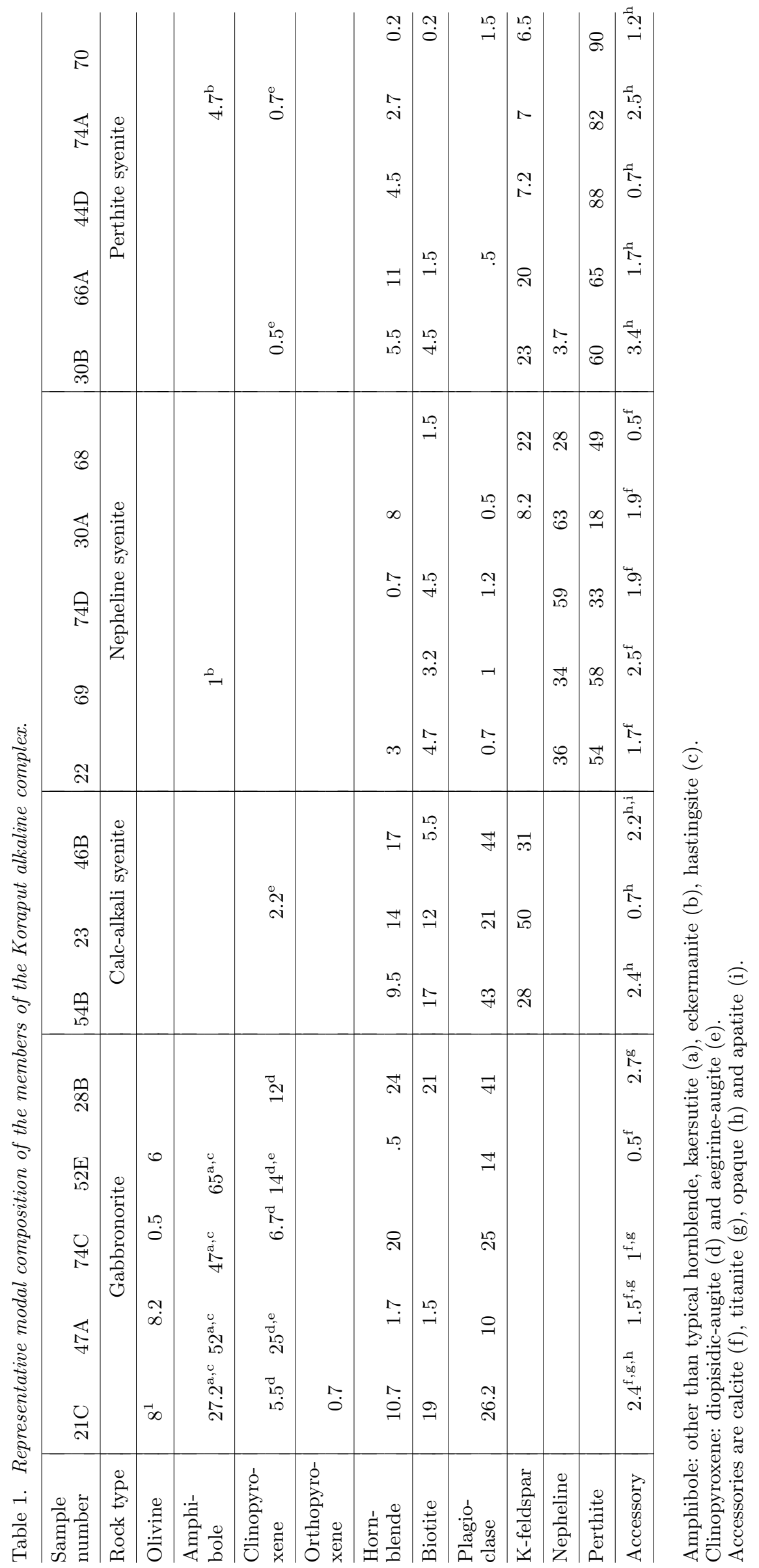



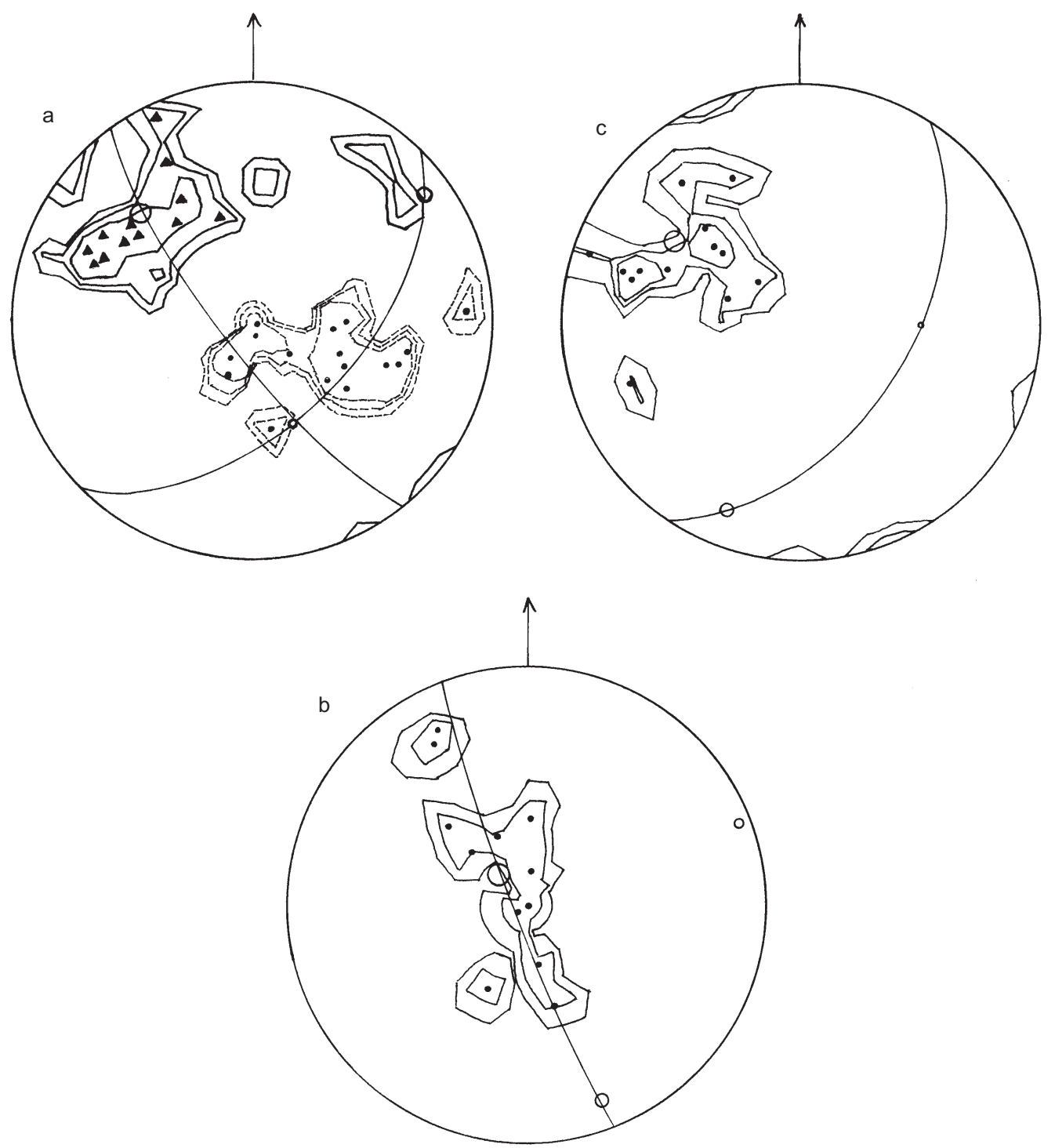

Figure 4. Stereograms: (a) Poles to mylonitic foliation (filled triangles) contoured at 1, 3, 5\% per $1 \%$ area and stretching lineation (filled circles) contoured at 1,3,5\% per $1 \%$ area. Great circles represent two possible mean orientations of shear zones; (b) Poles to $S_{1}$ in khondalite of location 55 (see figure 2), depicting a great circle distribution; pole to the great circle is nearly horizontal, indicating upright folding; (c) Poles to flow foliation in the alkaline complex, contoured at 1, 3, $5 \%$ per $1 \%$ area; great circle represents the mean orientation, nearly parallel to the orientation of the major shear zone.

\section{Discussion and implications}

Tectonic settings of continental alkaline complexes are commonly modeled from geochemical constraints in relation to the well-studied east African rift volcanics (Macdonald et al 1994). However, older rift provinces, such as the Proterozoic Gardar province of south Greenland exhibit considerably more plutonic components (Macdonald and Upton 1993) and for the plutonic alkaline complexes, such as those in the Eastern Ghats belt, tectonic setting should be deciphered from field structural data. And in most cases field structural data are lacking or inconsistent. Several alkaline intrusions have been reported from the Eastern Ghats gran- ulite belt, India, and we present a case study for the Koraput alkaline complex. This alkaline complex was first reported by Bose (1970), who proposed emplacement along a mega-fold developed in the enclosing granulitic country rocks. But, our detailed field studies around and across the complex reveals no large-scale folds. Instead, the intrusion definitely post-dates mesoscopic $F_{2}$ folds, and could relate to $F_{3}$ folding and associated extensional features: shear cleavage with a strike-slip component, elongated boudins, rod-like structures parallel to subhorizontal $F_{3}$ axes, reported from the Chilka Lake area (Bhattacharya 1997).

The emplacement of the Koraput alkaline complex in a pull-apart structure, as described here, 


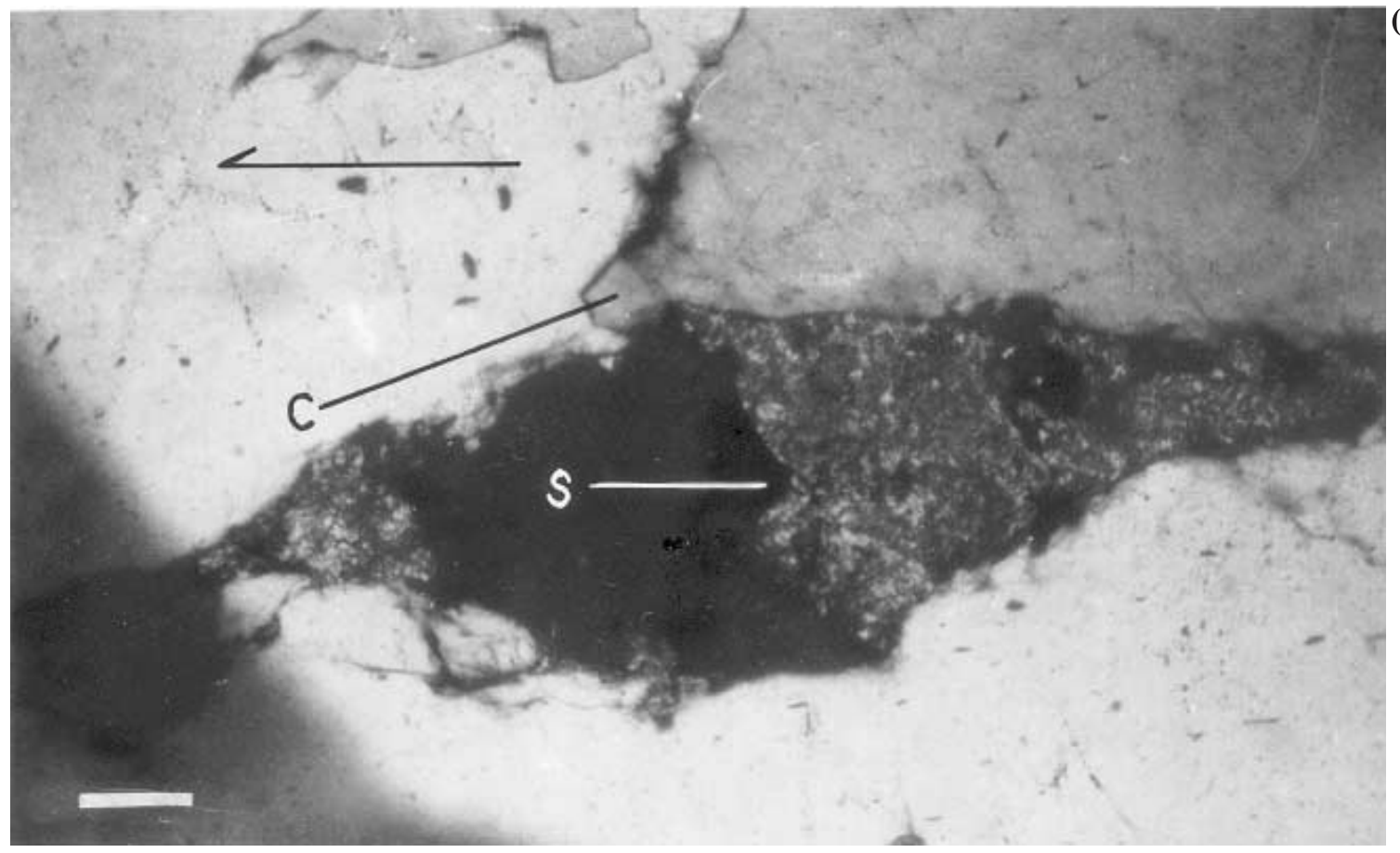

(a)

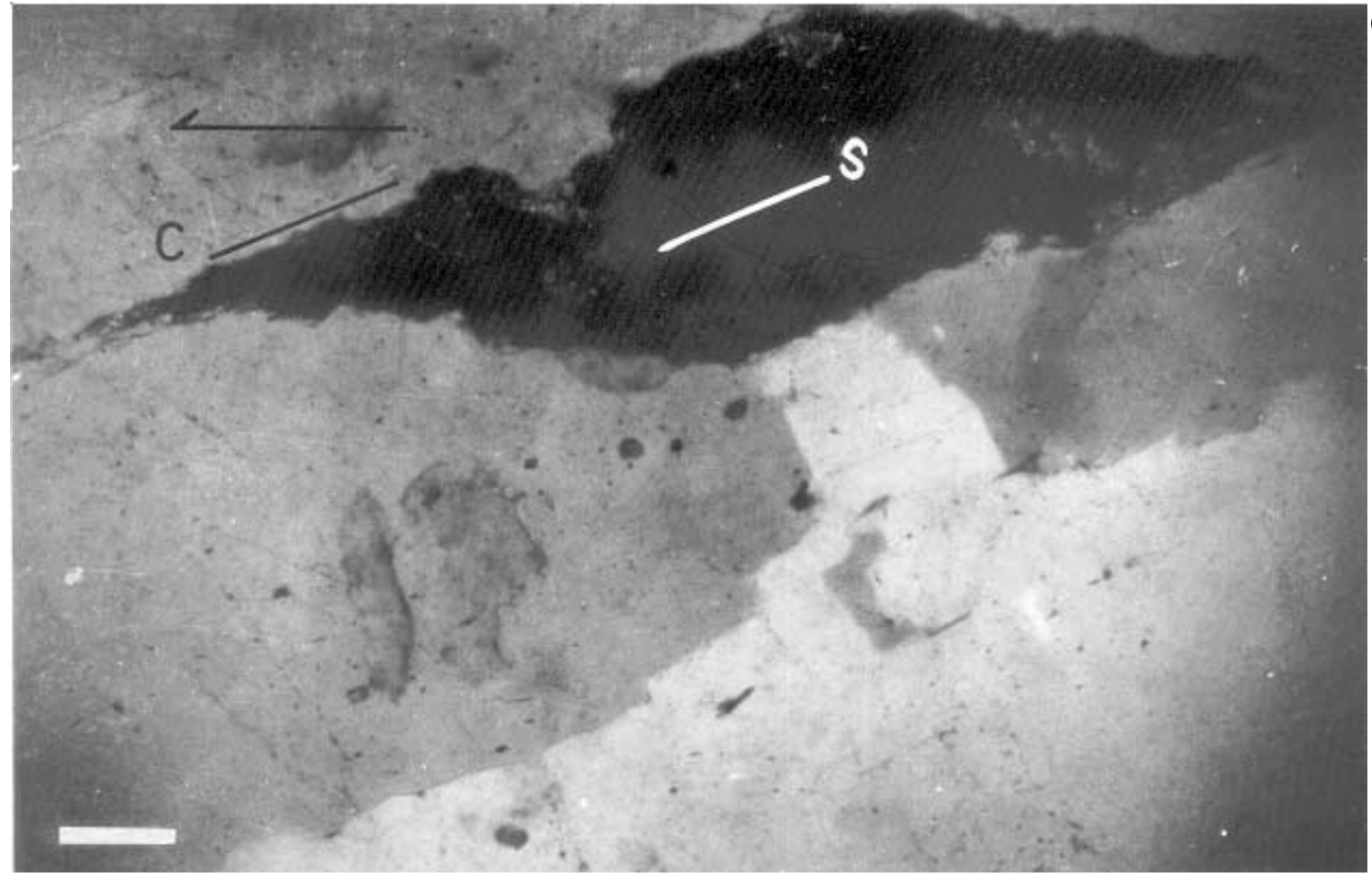

Figure 5. Photomicrographs of X-Z section of quartzite mylonite. (a) Sygmoidal polycrystalline quartz-mica blast; the truncating edges are parallel to the continuous cleavage $\mathrm{C}$ in the rock; the elongation of the quartz-mica blast depicts $\mathrm{S}$. (b) Sygmoidal mica-fish with truncating edges parallel to the continuous cleavage $\mathrm{C}$ in the rock and elongation of the mica-fish represents mylonitic banding S. Arrow points down plunge. The S-C relationship indicates normal fault sense of movement. Scale bar: $4 \mu$.

is consistent with the transcurrent shear zone cavity opening model of Hutton (1988) and similar to those reported for the Donegal granite, NW Ireland (Hutton 1982) and Mortagne granite, France (Guineberteau et al 1987).
On the other hand, the regional structuraltectonic studies suggest that the Eastern Ghats belt represents a convergent orogen that evolved under a regional NW-SE directed compression and attendant homogeneous shortening (Bhattacharya 

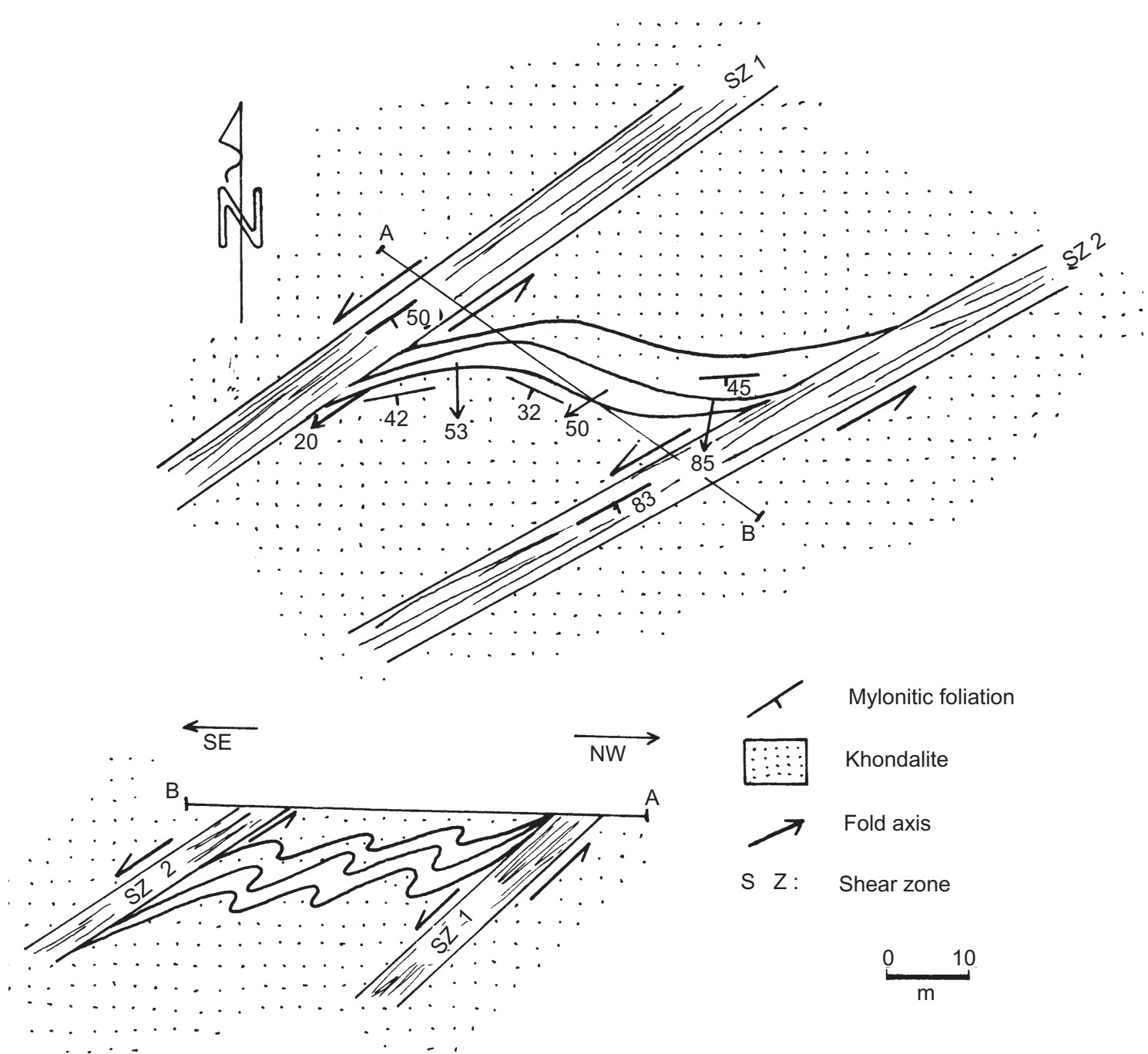

Mylonitic foliation

Khondalite

Fold axis

S Z: Shear zone

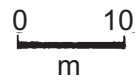

Figure 6. Map of a small shear lens in metapelite. Section along AB, looking from NE is also shown. Note sinistral-top towards NW normal fault sense of movement along the nearly parallel shear zones.

et al 2001). This is inconsistent with the idea that the Eastern Ghats belt represents a fault-bounded ensialic linear rift-zone (Leelanandam 1998). Moreover, the boundary between the Eastern Ghats belt and Bastar craton is marked by a crustalscale shear zone which developed at the time of collisional juxtaposition of the Eastern Ghats belt against the Bastar craton (Gupta et al 2000; Kar et al 2001; Bhattacharya 2002). Recently published geochronological data on the Eastern Ghats rocks revealed many complexities and the entire Eastern Ghats belt can no longer be considered as a single lithotectonic unit (Bhattacharya et al 2001; Rickers et al 2001). On the collision of the Eastern Ghats belt against the Bastar craton to the west, which is particularly relevant in the context of this paper, there is no published isotopic data. However, some unpublished data with the authors on charnockitic gneiss of the WCZ suggest a $2.5 \mathrm{Ga}$ collisional event post-dating charnockitic magmatism at $3.0 \mathrm{Ga}$. Kar et al (2001), presented microstruc- tural evidence of high-temperature shearing in the charnockitic rocks of the boundary area around Jaypur. Morphologically two distinct types of zircons were recovered from a charnockite gneiss. The prismatic zircons give ${ }^{207} \mathrm{~Pb} /{ }^{206} \mathrm{~Pb}$ age of ca. $3.0 \mathrm{Ga}$ and could be interpreted as crystallisation/emplacement age of the charnockitic magma. The rounded zircons, on the other hand, with ${ }^{207} \mathrm{~Pb} /{ }^{206} \mathrm{~Pb}$ age of $2.6 \mathrm{Ga}$, close to the lower intercept age of $2.5 \mathrm{Ga}$ and relatively poor in $\mathrm{U}(\sim$ $130 \mathrm{ppm})$ as against that in the prismatic zircons $(\geq 300 \mathrm{ppm})$, could represent reprecipitation and recrystallisation (Mezger and Krogstad 1997).

According to Leelanandam (1998), "all the feldspathoidal alkaline complexes of the Eastern Ghats belt are virtually restricted to the western margin and are significantly confined to the junction zone between the cratonic (non-charnockitic) and mobile belt (charnockitic) regions". However, according to Ramakrishnan et al (1998), alkaline complexes of EGMB are confined to the western 

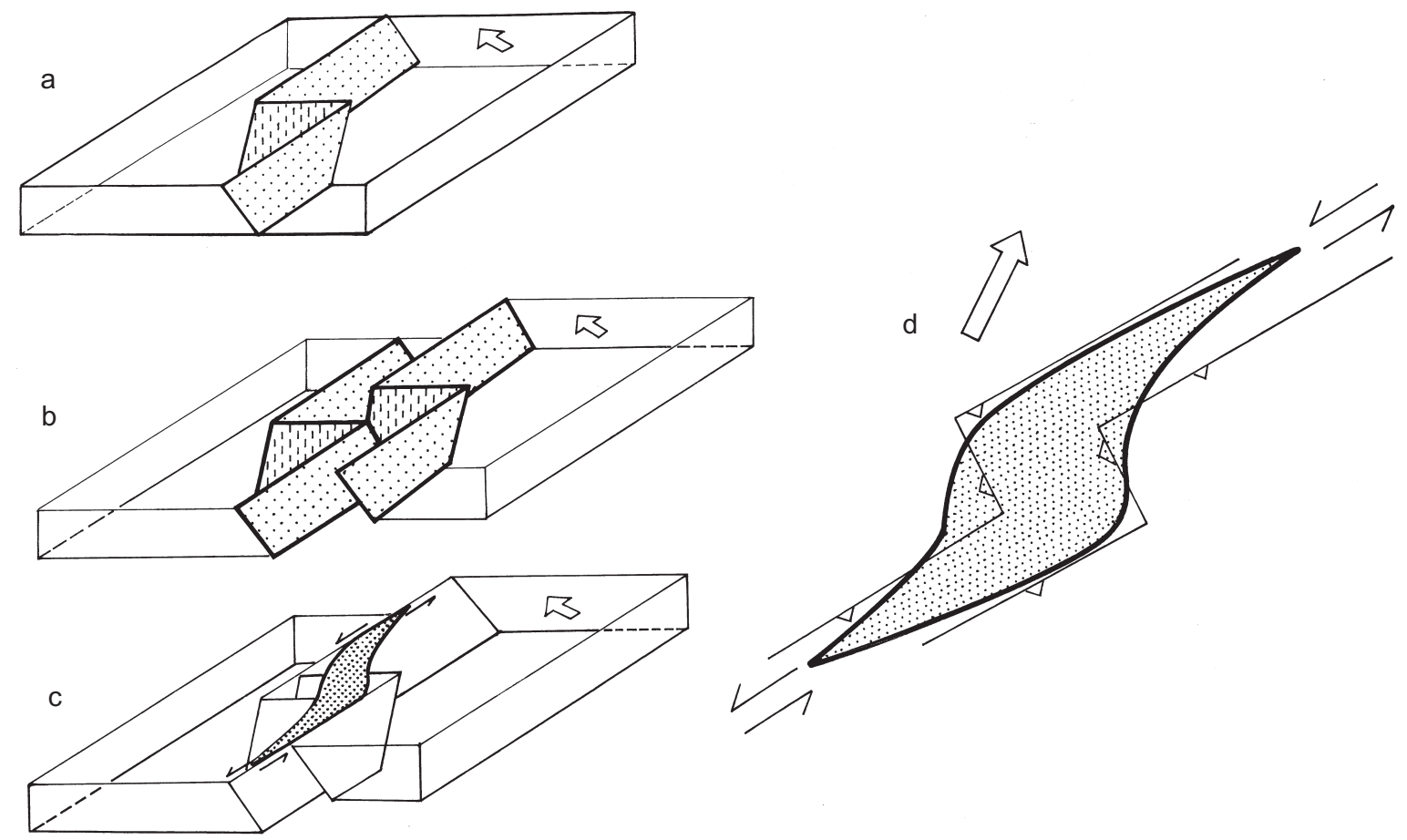

Figure 7. Model showing stages of emplacement of the alkaline magma along shear zone pathways. Arrow points towards north. (a) NE'ly trending dominant and NW'ly trending subsidiary shear zone; (b) sinsitral-top towards NW normal fault sense of movement along the dominant shear zone and reverse sense of movement along subsidiary shear zone, producing a gap, (c) sygmoidal gap is filled with alkaline intrusion (stippled), maximum width along NW and maximum elongation along NE and (d) schematic map of the model alkaline complex.

margin between the WCZ (western charnockite zone) and WKZ (western khondalite zone). The Koraput complex in particular occurs within the WKZ of Ramakrishnan et al (1998). Moreover, the supposed rifting of the continental margin, according to these authors, is separated from the main supracrustals of EGMB by the WCZ. Thus, the cryptic suture proposed by Leelanandam (1998) could, if at all, pertain to the contact zone between the cratonic and mobile belt regions; such a transition zone occurs to the west of the WCZ (cf. figure 2 in Ramakrishnan et al 1998). And above all, the Koraput alkaline complex is remote from the western boundary and no rift-tectonics can be envisaged.

The disposition of many of the alkaline complexes in the Eastern Ghats belt is, however, consistent with the alternative interpretation that they may represent local hot spots, and could trace the path of continents over mantle plumes (figure 1). Moreover, for the Koraput complex, movement along the principal northeasterly shear-zone is consistent with crustal thinning, which could have resulted from upwelling of mantle above some hotspots. Finally, it would be interesting to isotopically monitor these alkaline bodies in the Eastern Ghats belt, to verify any linear progression that would be expected if a plate moved over a plume (Foland \& Faul 1977).
It is significant that continental alkaline magmatism, particularly for a plutonic complex such as the Koraput complex, could be related to tectonism from field structural data and it would be encouraging to undertake similar studies for other plutonic complexes in the Eastern Ghats belt.

Also, in view of the indications that alkaline magmatism at Koraput is not associated with rifting or continental break-up, the alternative model of plume-tectonics for the alkaline complexes in the Eastern Ghats belt could be tested by isotopic monitoring.

\section{Acknowledgement}

Indian Statistical Institute provided the infrastructural facilities. Field work for this study was supported by the Council of Scientific and Industrial Research, Government of India, in the form of a project grant. The authors thankfully acknowledge critical comments of an anonymous reviewer.

\section{References}

Bailey D K 1974 Continental rifting and alkaline magmatism: In: The Alkaline rocks, (ed) H Sorensen (John Wiley \& Sons Ltd.) 148-159 
Bhattacharya S, Sen S K and Acharyya A 1994 Structural setting of the Chilka Lake granulite-migmatiteanorthosite suite with emphasis on the time relation of charnockites; Precam. Res. 66 393-409

Bhattacharya S 1997 Evolution of the Eastern Ghats granulite belt of India in a compressional tectonic regime and juxtaposition against Iron Ore Craton of Singhbhum by oblique collision-transpression; Proc.Indian Acad. Sci. (Earth Planet. Sci.) 106 65-75

Bhattacharya S, Kar R, Misra S and Teixeira W 2001 Early Archaean continental crust in the Eastern Ghats granulite belt, India: Isotopic evidence from a charnockite suite; Geol. Mag. 138 609-618

Bhattacharya S 2002 Nature of tri-junction in the East Indian Precambrians: Example from the Eastern Ghats granulite belt, Singhbhum Craton and Bastar Craton around Paikmal, Western Orissa; Gond. Res. 5 53-62

Bhattacharya S, Kar R, Teixeira W and Basei M 2003 Hightemperature crustal anatexis in a clockwise P-T-t path: isotopic evidence from a granulite-granitoid suite in the Eastern Ghats belt, India; J. Geol. Soc. London 160 $39-46$

Bose M K 1970 Petrology of the intrusive alkaline suite of Koraput, Orissa; J. Geol. Soc. India 11 99-126

Foland K A and Faul H 1977 Ages of White Mountain intrusives - New Hampshire, Vermont, and Maine; Am. J. Sci. 277 888-904

Guineberteau B, Bouchez J-L and Vigneresse J-L 1987 The Mortagne granite pluton (France) emplaced by pull-apart along a shear zone: structural and gravimetric arguments, regional implication; Bull. Geol. Soc. Am. $99763-770$

Gupta S, Bhattacharya A, Raith M and Nanda J K 2000 Contrasting pressure-temperature-deformation history across a vestigial craton-mobile belt boundary: the western margin of the Eastern Ghats belt at Deobhog, India; J. Met. Geol. 18 683-697

Halden N M, Bowes D R and Dash B 1982 Structural evolution of migmatites in a granulite facies terrane: Precambrian crystalline complex of Angul, Orissa, India; Trans. Roy. Soc. Edin. (Earth Sci.) $\mathbf{7 3}$ 109-118

Hutton D H W 1982 A tectonic model for the emplacement of the Main Donegal granite, NW Ireland; J. Geol. Soc. London 139 615-631
Hutton D H W 1988 Granite emplacement mechanisms and tectonic controls; Trans. Roy. Soc. Edin. $\mathbf{7 9}$ $245-255$

Kar R, Swain A K and Bhattacharya S 2001 Nature of craton-mobile belt boundary: an example from Bastar craton-Eastern Ghats mobile belt contact around Jaypur, Orissa, India; Indian J. Geol. 73 107-118

Leelanandam C 1998 Alkaline magmatism in the Eastern Ghats belt - A critique; Geological Survey of India Special Publication 44 170-179

Macdonald R L and Upton B G J 1993 The Proterozoic Gardar rift zone, south Greenland: Comparison with the East African Rift System. In: Magmatic Processes and Plate Tectonics; (eds) H M Pritchard, T Alabaster, N B W Harris, and C R Neary, Geol. Soc. Spec. Pub. 76 427-442

Macdonald R L, Williams A J and Gass I G 1994 Tectonomagmatic evolution of the Kenya rift valley: Some geological perspectives; J. Geol. Soc. London 151 879-888

Mezger K and Krogstad E J 1997 Interpretation of discordant U-Pb zircon ages: an evaluation; J. Met. Geol. 15 127-140

Philpotts A R 1990 Principles of Igneous and Metamorphic Petrology (New Jersey: Prentice Hall)

Ramakrishnan M, Nanda J K and Augustine P F 1998 Geological evolution of the Proterozoic Eastern Ghats Mobile belt; Geol. Surv. India Spec. Pub. 44 1-21

Rickers K, Mezger K and Raith M M 2001 Evolution of the continental crust in the Proterozoic Eastern Ghats Belt, India and new constraints for Rodinia reconstruction: implications from $\mathrm{Sm}-\mathrm{Nd}, \mathrm{Rb}-\mathrm{Sr}$ and $\mathrm{Pb}-\mathrm{Pb}$ isotopes; Precambrian Research 112 183-212

Sarkar A, Bhanumati L and Balasubramanyan M N 1981 Petrology, geochemistry and geochronology of the Chilka Lake igneous complex, Orissa state, India; Lithos 14 93-110

Sen S K, Bhattacharya S and Acharyya A 1995 A multistage pressure-temperature record in the Chilka Lake granulites: The epitome of metamorphic evolution of Eastern Ghats, India; J. Met. Geol. 13 287-98

Streckeisen A 1976 To each plutonic rock its proper name; Earth. Sci. Rev. 12 1-33 